（日本化学会誌，1986，（3 ），p. 306～311）

(C) 1986 The Chemical Society of Japan

\title{
アクセプター型ポリ(ジアセチレン) の合成と導電性
}

\author{
（1985 年 9 月 7 日 受 理)
}

内藤 勝 之*・水島 公一

1, 6-ジブロモ-2, 4-ヘキサジインは真空下加熱することにより重合して，共役系ポリマーを生成する。 ポリマーはジメチルスルホキシド (DMSO) やテトラヒドロフラン (THF) などの有機溶媒に可溶で あり, 薄膜状に成形できる。ポリマーはアクセプター性が強く、アンンニアやテトラチアフルバレン (TTF) などのドナーと電荷移動錯体を形成し, その電気伝導度は $10^{-1} \mathrm{~S} \cdot \mathrm{cm}^{-1}$ といちじるしく増加す る。しかし，ヨウ素やテトラシアノキノジメタン (TCNQ) などのアクセプター添加では電気伝導度は あまり増加しない。ポリマーの電気伝導度におよぼす温度, 圧力,ドーピング時間などの効果について 検討した。他の置換ジアセチレンポリマーについても検討し, アクセプター性の原因として, ポリマー の主鎖にプラス電荷が存在する共鳴構造の寄与を提案する。ポリ(ジアセチレン)のアクセプター性，ド ナー性は置換基を変えることにより制御でき, 置換基の種類とアクセプター性, ドナー性の関連および ポリマーとドーピング剤との関連について統一的に解釈する。

\section{1 腥 言}

ジフセチレン誘導体は結晶中や LB 膜中の固体状態においても 熱や電磁波の作用のみで重合し，共役鎖の伸びたポリマーを生成 する゙。ジアセチレン誘導体はその重合プロセスや，生成したポ リマーに期待される非線形光学効果 ${ }^{2}$ や導電性などの物性から近 年注目を集めている。導電性ポリマーとしてポリ(ジアセチレン) を見た場合，金属光沢を有するが，そのままでは絶緑体であり， 高導電化のためのドーピングも結晶性のためドーピング剤が入り にくいといら久点がある。これに対して近年, ドーピング重合や 電解ドーピング3)，イオン注入4)5)などによるポリ(ジセチレン) の高導電化や, 種々の置換基の導入による高導電化 ${ }^{3)(日)}$ などが行 なわれている。

一方，上記のポリ(ジアセチレン)を含めて従来の導電性ポリマ 一はドナー性が強く、ヨウ素や五フッ化ヒ素などのアクセプター

株式会社東芝総合研究所化学材料研究所, 210 川崎市幸 区小向東芝町

1) .H. J. Cantow Ed., "Advances in Polymer Science 63, Polydiacetylenes”, Springer-Verlag (1984).

2) たとえば, C. Sauteret, J.-P. Hermann, R. Frey, F. Pradère, J. Ducuing, Phys. Rev. Lett., 36, 956(1976).

3) 松田宏雄, 中西八郎, 飯島誠一郎, 田中芳雄, 加藤政雄, 第 33 回高分子討論会予稿集, p. 2519(1984).

4) 和田莲夫, 岩木正哉, 隹部博之, 中西八郎, 松田宏雄, 加 藤政雄，第 34 回高分子年次大会予稿集，p. 528(1985).

5) M. Sakamoto, B. Wasserman, M.S. Dresselhaus, G. E. Wnek, B. S. Elman, D. J. Sandman, J. Appl. Phys., to be sufmitted.

6）畏谷川 卉, 大沼 宏, 小高忠男, 第 32 回高分子討論会 予稿集, p. 2681(1983).

7) 栗原 隆, 海老沢文博, 田部井久男, 第 33 回高分子年次 大会予皘集，p.460(1984).
をドーピングした例がほとんどであり，ドナーをドーピングし た例はアルカリ金属などの強力なるのの例を除けばほとんどな $\left({ }^{8)}\right.$ 。

著者らはハロゲン置換されたポリ(ジアセチレン)のアクセプタ 一性が強く、アンモニアなどの弱ドナーをドーピングすることに よりいちじるしく電気伝導度が上昇することを見いだした。本研 究では八ロゲン置換ポリ(ジアセチレン)の導電性を中心とした物 性についての検討ならびに, 種々の置換ポリ(ジアセチレン)とド ーピング剤との関連について検討した。

\section{2 実験}

\section{1 試 薬}

1,6-ジブロモ-2,4-ヘキサジインは 2,4-ヘキサジイン-1, 6-ジ オール（市販品をエタノール中から再結晶）と三臭化リン（市販 品そのまま) を反応させて合成した9)。重合はアンプル中に 1, 6ジブロモ-2,4-ヘキサジイン $0.2 \mathrm{~m} l$ を真空下封じて徐々に加熱 し, 最終的に $100^{\circ} \mathrm{C}$ で 20 時間反応させた。急激な加熱では爆発 的に反応した。生成した黒蝎色の固体をメタノール, 石油エーテ ルで洗うことにより $0.33 \mathrm{~g}$ のポリマーを得た。

2,4-ヘキサジイン-1,6-ジイルジトシレートは 2,4-ヘキサジ イン-1, 6-ジオールと塩化トシルから常法により合成し、その単 結晶を真空下 $90^{\circ} \mathrm{C} て ゙ 2$ 日間加熱することにより単結晶ポリマー を得だ。

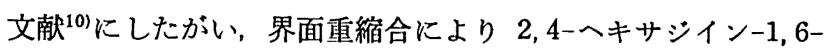

8）白川英樹, 山邊時雄編, “合成金属”, 化学同人 (1980).

9) J. B. Armitage, W. C. Whiting, J. Chem. Soc., 1952, 2005.

10) A. O. Patil, D. D. Deshpande, S. S. Talwar, A. B. Biswas, J. Polym. Sci., Polym. Chem. Ed., 19, 1155 (1981). 
ジオールとアジピン酸ジクロリドを重合し，白色のポリェステル を得た。ポリエステルをペレット状木たはフィルム状に成形して から真空下加熱し，ジアセチレン部分を反応させ橋かけさせた赤 色のポリエステルを得た。

アンモニアガスはボンベ入り市販品を, 塩化ホスホリル, テト ラチアフルバレン (TTF), テトラシアノキノシメタン(TCNQ), ヨウ素も市肘品をそのまま用いた。

\section{2 生成ポリマーの分析}

IR スペクトルは日本分光製 IRA-2 型赤外分光光度計を用い, $\mathrm{KBr}$ 錠剤法により測定した。ゲルパーミェーションクロマトグ ラムは東洋曹達製 HCL-802 A 高速液体クロマトグラフを用い, 単分散ポリスチレンを基準とし，テトラヒドロフラン (THF) を 展開溶媒として測定した。電子スペクトルは日立製 330 型自記 分光光度計を用い, THF または $N, N$-ジメチルホルムアミド (DMF) を溶媒として測定した。X線散乱スペクトルは自作品を 用い,キャストフィルム状の試料を測定した。キャストブィルム の膜厚は Rank Taylar Hobson 製 Talystep 膜厚計を用いて测定 した。

\section{3 電気伝導度の測定}

電気伝導度の測定はおもに白金線で外部と導通をとったフラス コに試料を入れ，真空に引いたあとにドーピング剤を導入して直 流四端子法もしくは二端子法により行なった。

1,6-ジブロモ-2,4-ヘキサジインポリマーの測定試料はそのジ メチルスルホキシド (DMSO) 溶液もしくはクロロホルム溶液を 金電極を蒸着したガラス上にキャス、トしたのち，空気中で放置す ることにより得た。1,6-ジブロモ-2,4-ヘキサジインポリマー と TTF むしくは TCNQ との混合系はその DMSO 溶液を金電 極を蒸着したガラス上にキャストしたのち，窒素気流中で放置す ることにより得た。2,4-ヘキサジイン-1, 6-ジイルニジトシレート の単結晶ポリマーおよび 2,4-ヘキサジイン-1,6-ジオールとアジ ピン酸クロリドの橋かけポリエステルのペレットは銀ペーストで 電極をとり，同様にフラスコ内で電気伝導度を測定した。

\section{3 結 果}

3.1 1,6-ジフロモ-2,4-ヘキサジインポリマーのキャラクタリ ゼーション

モノマーの加熱により得られた黒褐色の粉末はメタノール， 水, 石油エーテルに不溶, クロロホルム, ジメルスルホキシド (DMSO)，テトラヒドロフラン (THF) には可容であった。ゲル パーミエーションクロマトグラフィーによる測定ではボリスチレ ン換算で分子量は 25000 ，分子量分布は 2.0 であった。 図1にモノマーとポリマーの IR スペクトルを示す。 ポリマーではジアセチレンの吸収 $\left(2150,2250 \mathrm{~cm}^{-1}\right)$ が消え, 炭素-炭素不飽和二重結合の吸収が現われている。その他のピー クも幅広くなっている。

ポリマーの電子スペクトルは $270 \mathrm{~nm}$ に肩吸収があるはかは,

長波長側に向かって吸光度は徐々に減少している。 ポリマーのキャストフィルムのX線散乱スペクトルを図 2 に示

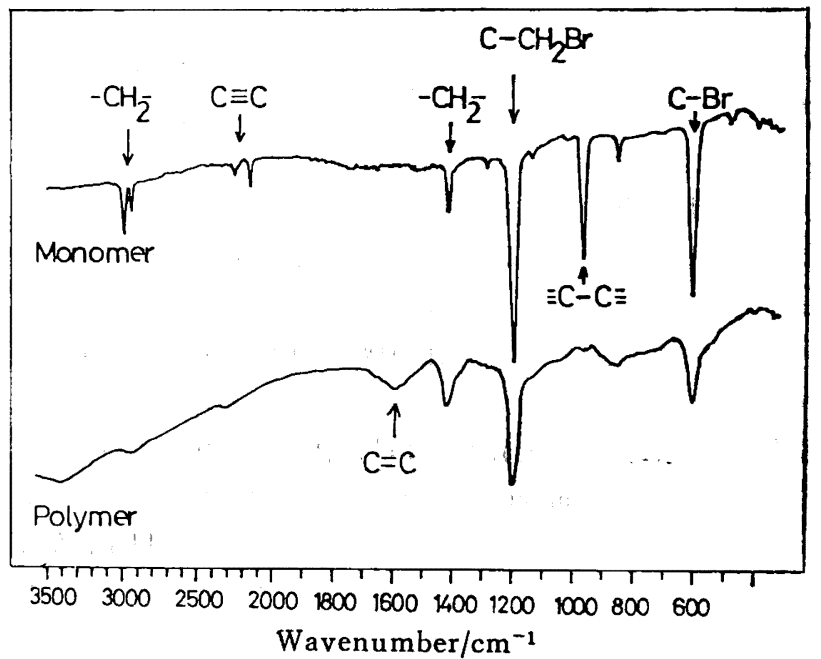

Fig.1 IR spectra of monomer and polymer of 1,6dibromo-2, 4-hexadiyne

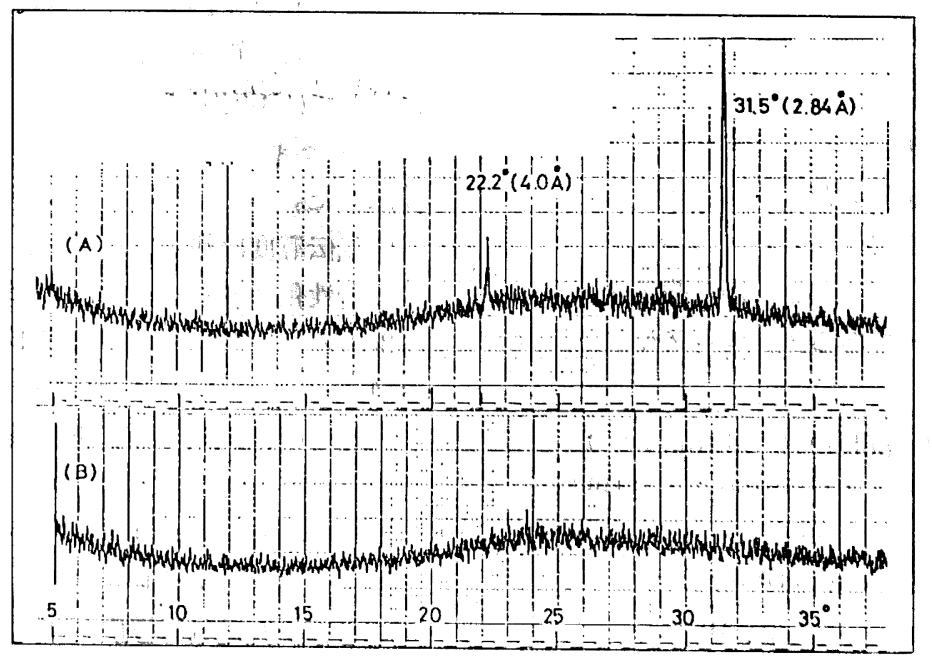

$2 \theta$

Fig. $2 \mathrm{X}$-ray diffraction spectra of poly (1,6-dibromo-2, 4-hexadiyne) films cast from dimethyl sulfoxide (A) and chloroform (B) solutions 
す。

ポリマーのクロロホルム溶液からのキャストフィルムは透明で ピークは観測されずフモルファスであるが，DMSO 溶液からの キャストは不透明であり，4.0 と $2.8 \AA$ の面間隔を示す鋭いピー クが観測され，結晶性がかなり高いことが示された。

\section{2 ポリジアセチレンとドナーとの電荷移動錯体形成}

1,6-ジブロモ-2, 4-ヘキサジインポリマーのテトラヒドロフラ ン (THF) 溶液の電子スペクトルはジェルアミンを添加すると 短波長 $(250 \sim 300 \mathrm{~nm})$ の吸収が減少し, 長波長 (300〜800 nm) の吸収が増大した。1,6-ジブロモ-2,4-ヘキサジインポリマーの クロロホルムとテトラチアフルバレン (TTF) のクロロホルム溶 液を混合すると黒赤紫色の沈殿が生成した。沈䟝の $N, N$-ジメチ ルホルムアミド (DMF) 溶液の電子スペクトルには $585 \mathrm{~nm}$ に電 荷移動に基づくと考えられる吸収ピークが観測された。

2,4-ヘキサジイン-1, 6-ジイル=ジトシレートの単結晶ポリマー をアンモニアガス中や，トリエチルアミン中，またはトリフェニ ルホスフィンの THF 溶液中に置くと単結晶表面は黄金色から黒 紫色に変化した。2,4-ヘキサジイン-1,6-ジオールとアジピン酸 ジクロリドとの橋かけポリエステルをアンモニアガス中に置くと 赤色から黒色に変化した。しかしヨウ素ガス中では変色しなかっ た。

\section{3 ポリ(ジアセチレン) の導電性}

3.3.1 1, 6-ジブロモ-2,4-ヘキサジインポリマーの導電性 : 1, 6-ジブロモ-2,4-ヘキサジインポリマーのキャストフィルム（膜 厚 $2.1 \mu \mathrm{m}$ ) は真空下では電気伝導度が $10^{-11} \mathrm{~S} \cdot \mathrm{m}^{-1}$ 以下の絶縁 体であるが， 1 気圧のアンモニアガスをドーピングすることによ り電気伝導度は急激に上昇して 1 時間後に $5 \times 10^{-2} \mathrm{~S} \cdot \mathrm{cm}^{-1}$ に達 した。ドーピングは可逆的であり，真空に引いてアンモニアガス を除去すると電気伝導度はただちに $10^{-11} \mathrm{~S} \cdot \mathrm{cm}^{-1}$ 以下に低下し た。表 1 に種々の膜厚のキャストフィルムのアンモニア 1 気圧下 の電気伝導度を示した。フィルムは $10^{-1} \sim 10^{-2} \mathrm{~S} \cdot \mathrm{cm}^{-1}$ の電気伝 導度を与えている。

アンモニア死が減少すると電気厷導度はアンモニア圧に対して 指数関数的に減少する。アンモニア圧 1 気圧下における電気伝導 度の温度変化を図 3 に示す。

$10 \sim 30^{\circ} \mathrm{C}$ では電気伀導度はほぼ一定であるが，30〜 $50^{\circ} \mathrm{C}$ では 温度が増大すると電気伝導度は 3 ケ減少している。

表 2 に 1,6-ジブロモ-2,4-ヘキサジインポリマーの種々のドー ピング剂による電気公導度の変化を示した。

弱フクセプターであるヨウ素やテトラシフノキノジタン （TCNQ）では電気伝導度はあまり上昇しないが，強アクセプタ 一である塩化ホスホリルや弱ドナーであるアンモニアやテトラチ

Table 1 Conductivities of poly(1,6-dibromo-2, 4hexadiyne) films in an anmonia(1 atm) atmosphere

\begin{tabular}{cc} 
Thickness $(\mu \mathrm{m})$ & Conductivity $\left(\mathrm{S} \cdot \mathrm{cm}^{-1}\right)$ \\
\hline 0.07 & $2 \times 10^{-1}$ \\
0.22 & $9 \times 10^{-3}$ \\
1.2 & $1 \times 10^{-2}$ \\
2.1 & $5 \times 10^{-2}$ \\
4.8 & $8 \times 10^{-2}$ \\
12 & $1 \times 10^{-1}$
\end{tabular}

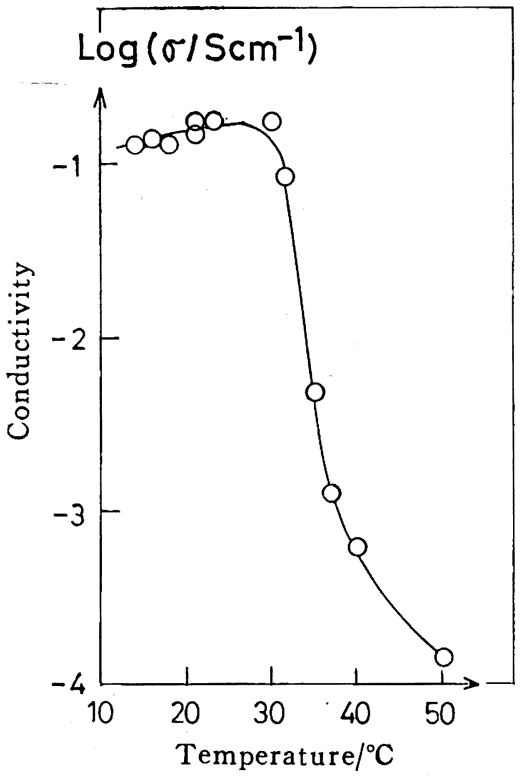

Fig. 3 Temperature dependence of conductivity of poly (1, 6-dibromo-2, 4-hexadiyne) in an ammonia (1 atm) atmosphere

Table 2 Conductivities of poly(1,6-dibromo-2, 4-hexadiyne) with various dopants

\begin{tabular}{ccc}
\hline (Donor) & Dopant & $\begin{array}{c}\text { Conductivity } \\
\left(\mathrm{S} \cdot \mathrm{cm}^{-1}\right)\end{array}$ \\
\hline- & (Acceptor) & $<10^{-11}$ \\
- & - & $4 \times 10^{-6}$ \\
- & $\mathrm{I}_{2}{ }^{a}$ & $3 \times 10^{-7}$ \\
- & $\mathrm{TCNQ}^{b)}$ & $1 \times 10^{-3}$ \\
$\mathrm{NH}_{3}{ }^{d)}$ & - & $10^{-1} \sim 10^{-2}$ \\
$\mathrm{PTF}^{c)}$ & - & $10^{-1} \sim 10^{-2}$
\end{tabular}

a) $0.2 \mathrm{mmHg}$.

b) Monomer unit $/ \mathrm{TCNQ}=1 / 1$ (molar ratio).

c) $12 \mathrm{mmHg}$.

d) $760 \mathrm{mmHg}$.

e) Monomer unit $/ \mathrm{TTF}=1 / 1$ (molar ratio).

アフルバレン (TTF) のドーピングにより電気伝導度は大幅に上 昇している。TTF 添加系は乾燥空気には安定であったが, 湿気 に対しては不安定で電気伝導度は低下した。図4に1,6-ジブロ モ-2,4-ヘキサジインポリマー/TTF 系の電気伝導度の温度变化 を示した。

電気伝導度は熱エネルギー活性型であり，330～160 K のみか けの活性化エネルギーは $0.15 \mathrm{eV}$ である。

3.3 .2 他のポリ(ジアセチレン) の導電性 : 2 ,4-ヘキサジイ ン-1, 6-ジイルニシトシレートの単結晶ポリマーは 1 気圧のアンモ ニアガス中に放置することにより, 電気伝導度は $10^{-13} \mathrm{~S} \cdot \mathrm{cm}^{-1}$ 以下から 66 時間後に $4 \times 10^{-6} \mathrm{~S} \cdot \mathrm{cm}^{-1}$ まで上昇した。

2, 4-ヘキサジイン-1, 6-ジオールとアジピン酸ジクロリドの橋 かけポリエステルペレットは 1 気圧のアンモニアガス中に放固す ることにより電気伝導度が $6 \times 10^{-15} \mathrm{~S} \cdot \mathrm{cm}^{-1}$ から 19 時間後に 3 $\times 10^{-5} \mathrm{~S} \cdot \mathrm{cm}^{-1}$ まで上昇した。

図 5 にドーピング時間に対する電気伝導度の变化を示した。 電気伝尊度の上昇は 1,6-ジブロモ-2,4-ヘキサジインポリマー フィルムにくらべてゆるやかであり, 真空に引いてアンモニアを 


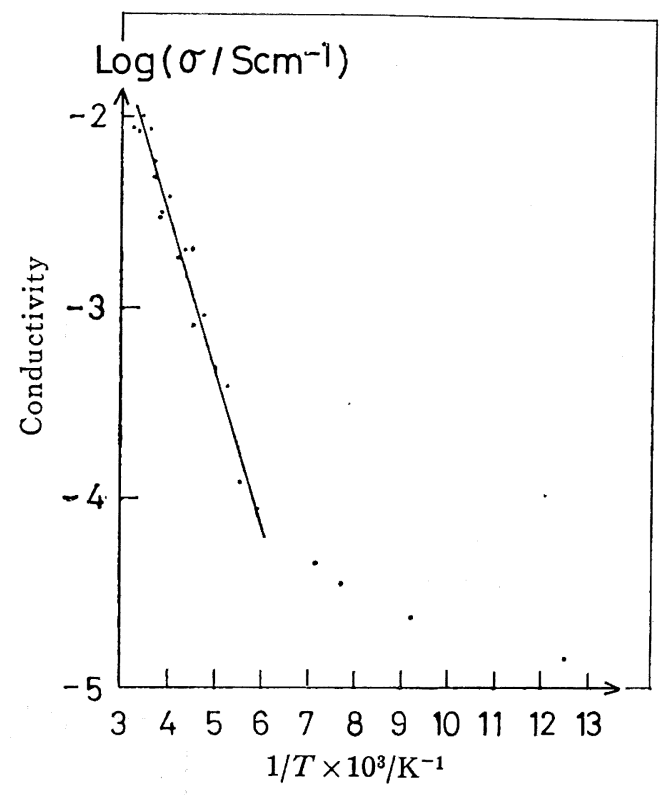

Fig. 4 Temperature dependence of conductivity of poly (1, 6-dibromo-2, 4-hexadiyne)/tetrathiafulvalene $(\mathrm{TTF}$ ) (monomer unit $/ \mathrm{TTF}=1 / 1 \mathrm{molar}$ ratio)

除去すると電気伝導度はゆっくりと低下する。アンモニアガス中 に放置したこれらのポリ(ジアセチレン) はもろくなり，IR スペ クトルからスルホン酸エステル拈よびカルボン酸エステル結合が 切断されていることがわかった。

\section{4 考察}

\section{1 ポリマーの導電性とアクセプター性}

結果で述べたことはポリ(ジアセチレン) とアンモニアや TTF などのドナーが電荷移動錹体を形成し，電気伝導度が錯体の濃度 に依存していると仮定することにより説明できる。

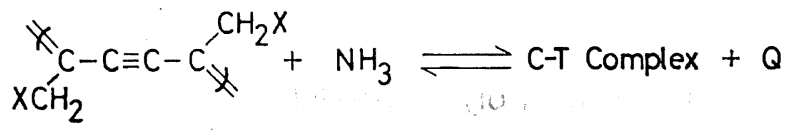
(Acceptor) (Donor)<smiles>[Y]=CSOS(=O)(=O)c1ccc(C)cc1</smiles>

図 3 に扣いて $30 \sim 50^{\circ} \mathrm{C}$ で温度が増加すると電気伝導度が減少 するのは( 1 )式の錯体形成反応が発熱反応で, 高温では平衡が左 側にずれるためと考えられる。10〜30 ${ }^{\circ} \mathrm{C}$ では電気伝導度が一定 となるのは半導体としての性質と鍇形成反応が打ち消し合らため と考えられる。

ポリマーのアクセプター性の原因としては次式で示す共鳴構造 の笴与が考光られる。

Armitage らのによれば, $\mathrm{XCH}_{2}-\mathrm{C} \equiv \mathrm{C}-\mathrm{C} \equiv \mathrm{C}-\mathrm{CH}_{2} \mathrm{X}$ の電子スペク トルは式 ( 3 )の順に長波長シフトし，モル吸光係数も增大する。 彼らはその原因として（2）式と同様な共鳴構造の笴与が增大し てくるためとしている。実際, 11,6-ジブロモ-2,4-へキサジイン $(\mathrm{X}=\mathrm{Br})$ や， 2,4-ヘキサジイン-1,6-ジイルニジトシレート（X=

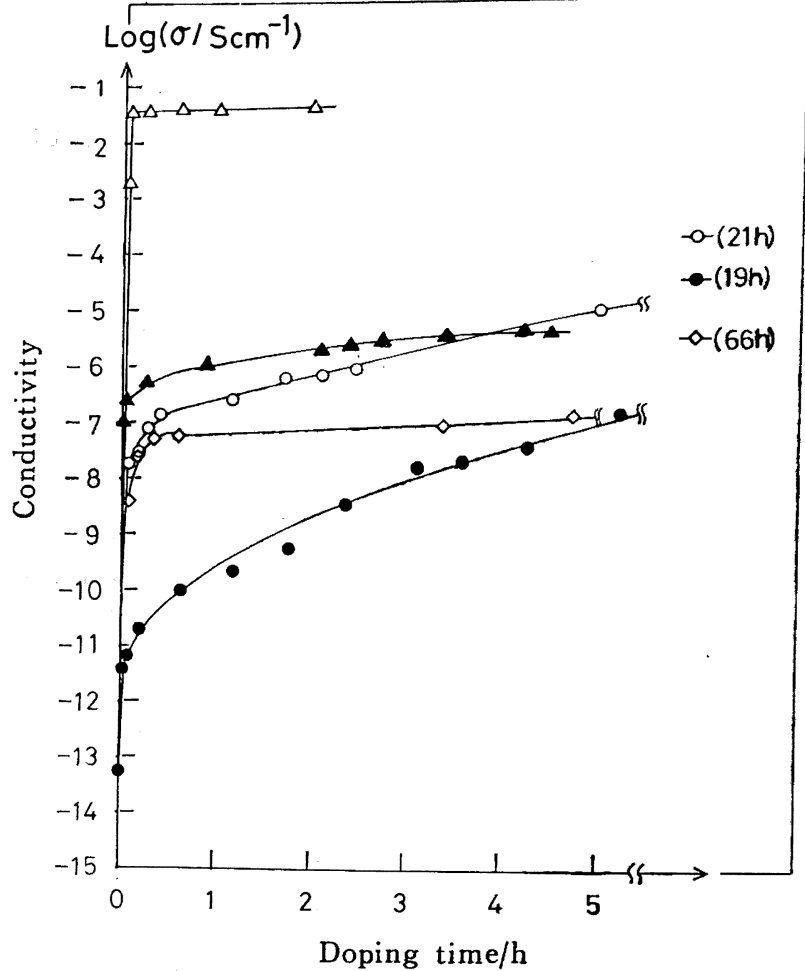

Fig. 5 Doping-time dependence of conductivity of poly(diacetylene)s<smiles>[X]CC1=CC1CC([X])(C)C</smiles>

$\Delta: X=\operatorname{Br}(2.1 \mu \mathrm{m}$ film $) \mathrm{NH}_{3}$ doping

$\Delta \cdot X=B r(0.5 \mu \mathrm{m}$ film $) I_{2}$ doping

$\diamond: \mathrm{X}=\mathrm{OSO}_{2}$ 『 $\mathrm{CH}_{3}$ (crystal) $\mathrm{NH}_{3}$ doping

$\mathrm{O}: \mathrm{X}=\mathrm{O}_{\mathrm{O}}^{\mathrm{O}}-\mathrm{CH}_{2} \mathrm{t}_{4} \mathrm{~N} \mathrm{O}-(2.5 \mu \mathrm{m}$ tilm $) \mathrm{NH}_{3}$ doping

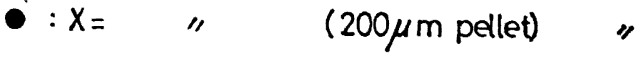

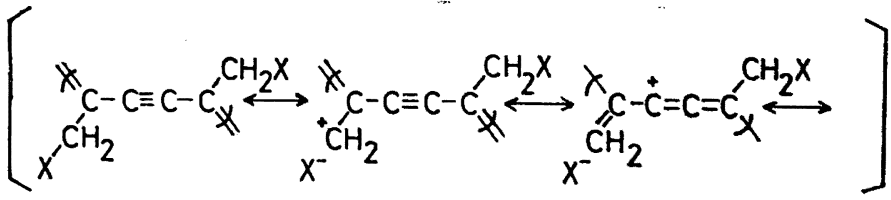

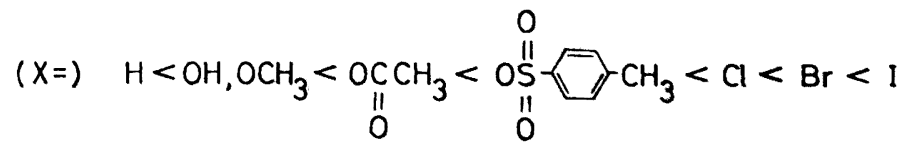

$\left.\mathrm{OSO}_{2}-\bigcirc-\mathrm{CH}_{3}\right)$ はジメチルスルホキシド中, トリフェニル ホスフィン（ドナー）を加えると黑色に変化（電荷移動錯体形成） するが, 2,4-へキサジイン-1,6-ジオール $(\mathrm{X}=\mathrm{OH})$ では变化しな かった。このことから、アクセプター性す（3)式の暊に增大する と考兄らる。 
4.2 ポリマーとドービンク威の関係

ポリマーとドーピング剤の定性的な関係を図 6 亿示寸。ポリア セチレンはドナー性が強く, 弱アクセプターであるヨウ素と強ド ナーであるナトリウムは同程度の電気伝導度を与えるが, 弱ドナ 一であるフンモニアでは電気伝導度は上昇しない(11)。

一方，1,6-ジブロモ-2,4-ヘキサジインポリマーはアクセプタ 一性が強く、弱アクセプターでは電気伝導度はあまり上昇しない が、弱ドナーをドーピングすることにより電気伝導度がいちじる しく上昇する．ポリ（ジアセチレン）は固換基を変えることによ クアクセプター性, ドナー性を制御することが可能であり,ドナー

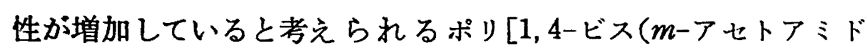
$フ_{ェ}$ ニル)-1,3-ブタジイン] (mAAPB : 図6 参照) やポリ $[1,4-$ ビス[3-(2-ブトキシ-2-オキソェチルアミノカルボニルオキシ)プ ロピル]ブタ.ジイン]6) (3 BCMU：図6参照)はヨウ素をドーピ ングするとにより電気伝導度がいちしるしく上昇している。臭 素や塩素に対するポリ(ジアセチレン) の安定性も同様にドナー 性が增加すると低下している(2)13)。

\section{5 結 論}

1,6-ジプロモ-2,4-ヘキサジインポリマーはアクセプター性が 強く，弱ドナーをドーピングすることにより電荷移動錹体を形成

11) C. K. Chiang, M. A. Druy, S.C. Gau, A. J. Heeger, E. J. Louis, A. G. MacDiarmid, Y.W. Park, H. Shirakawa, J. Am. Chem. Soc., 100, 1013(1978).

12) G. N. Patel, H. R. Bhattacharjee, A.F. Preziosi, J. Polym. Sci., Polym. Lett. Ed., 19, 511(1981).

13) D. Bloor, C. L. Hubble, D. J. Ando, Nato Conf. Ser., 6. 243(1978).

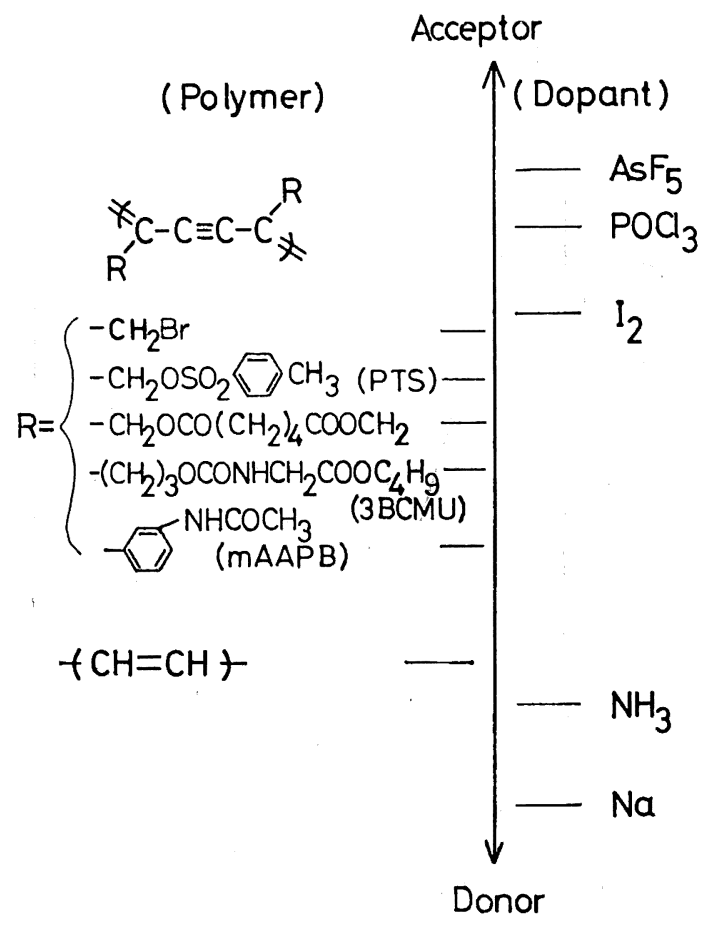

Fig. 6 Relations among polymers and dopants

し, 電気伝導度がいちじるしく增加する。ポリ（ジアセチレン）の アクセプター性, ドナー性は置換基を变えることにより制御でき る。

本研究は日本化学会第 50 春季年会 (1985年 4 月), 高分子学会 第34回年次大会 (1985 年 5 月), 第 34 回高分子討論会 (1985 年 9 月）溌表済である。

\title{
Special Articles on \\ Electrically Conducting Materials and Their Applications
}

\author{
Synthesis and Electric Conduction of Acceptor-Type Poly(diacetylene)
}

\author{
Katsuyuki NaIto* and Koichi Mizushima \\ Chemical Labolatory, Toshiba $R \&$ D Center; Komukai Toshiba-cho, \\ Saiwai-ku, Kawasaki-shi 210 Japan
}

\begin{abstract}
1,6-Dibromo-2, 4-hexadiyne has been polymerized in a vacuum by heating, resulting in the formation of a conjugated polymer. The polymer is soluble in dimethyl sulfoxide (DMSO) and tetrahydrofuran (THF), and can be formed into thin films. Its molecular weight is estimated at 25000 by gel permeation chromatography (GPC). The polymer is an acceptor and makes change-transfer (C-T) complexes with donors such as ammonia and tetrathiafulvalene (TTF). Consequently, its conductivity increases to $10^{-1} \mathrm{~S} \cdot \mathrm{cm}^{-1}$, as shown in Table 1 and 2. Acceptor molecules such as iodine and tetracyanoquinodimethan (TCNQ), however, don't cause the conductivity to increase very much (up to $10^{-6}-10^{-7} \mathrm{~S} \cdot \mathrm{cm}^{-1}$ ). That is quite different from the property of the usual conducting polymers such as polyacetylene. The single crystal of poly (2, 4-hexadiyne-1,6-diyl ditosylate) and the pellet of the cross-linked polyester made from 2, 4-hexadiyne-1,6-diol and adipoyl dichloride also form the C- $\mathrm{T}$ complexes with ammonia, their conductivities being raised up to $10^{-4}-10^{-6} \mathrm{~S} \cdot \mathrm{cm}^{-1}$, as shown in Fig. 5. The electron-withdrawing abilities of these poly(diacetylene)s depend on their reso-
\end{abstract}


nance structure shown in Equation (2): the positive charge exists on their polymer backbones, and the negative one on their substituents. The strength of poly(diacetylene) as acceptor or as donor can be controlled by changing its substituent. The acceptor-donor relations among poly(diacetylene)s and dopants are proposed in Fig. 6. 